\title{
O ESPAÇO RELIGIOSO, A GEOGRAFIA E A MPB: uma proposta para o ensino médio
}

\author{
Rui Ribeiro de Campos* \\ PUC Campinas
}

O passado nunca conhece o seu lugar $O$ passado está sempre no presente. Mário Quintana (1906-1994)

A cultura é um conjunto de saberes, técnicas, crenças e valores, cunhado no interior das relações sociais de uma sociedade de classes. Possui, portanto, um sentido político e, muitas vezes, expressa a relação social de quem faz uma música ou para quem ela foi feita. O que se pretende fazer aqui é um breve panorama de letras de músicas da MPB gravadas e divulgadas pelos meios de comunicação de massa relativas a religiões e não abordar a produção realmente popular, inclusive pela dificuldade de acesso a esta. Portanto, o que se pretende é uma abordagem cultural específica na Geografia, visando o uso deste instrumento em sala de aula, para facilitar a compreensão dos mundos vividos por parcela significativa de brasileiros.

Um dos temas abordados pela Geografia é a religião, criadora de espaços urbanos no Brasil e de movimentos em diversos locais. "Talvez seja impossível entender a humanidade sem a alma religiosa do ser humano. Mas também não é possível ler a história humana sem nos depararmos com tantas guerras promovidas em nome de Deus, mas que ocultavam interesses imediatos dos envolvidos".

\footnotetext{
* Mestre em Educação pela PUC-Campinas, doutor em Geografia pela UNESP-Rio Claro e professor na Faculdade de Geografia da PUC-Campinas.
} 
(MALVEZZI, 2004:18) Do mesmo modo, é difícil entender parte da história do Brasil, de sua organização espacial e as características de sua população. sem analisar as características e as influências principalmente da Igreja Católica. Hoje. no país, convivem catolicismo popular, cultos afro-brasileiros, cultos evangélicos c igrejas criadas com fins escusos. Para cada um deles, a espacialidade sagrada e profana adquire formas e significados próprios, muitas vezes superpostos. Entretanto, o destaque aqui será dado ao cristianismo pelo papel que possuiu em grande parte da população brasileira.

Isto é o que caracteriza parcela da população brasileira que hoje não possui necessariamente aquela religião obrigatória, mas que crê de diversas maneiras e acha importante possuir uma fé. É o que diz a canção gravada por Gilberto Gil em agosto de 1982 no disco U/m Banda Lim. Atente para o termo faiá, uma tentativa de legitimar uma forma popular do verbo fallar.

\section{ANDAR COM FÉ (Gilberto Gil)}

Andar com fé eu vou/ Que a té nio costuma "faiā" Andar com fé eu vou/ Que a fé nào costuma "faiâ"/ Andar com tê eu vou/ Que a fé não costuma "fàá".

Que a fé tá na mullıer/ A fé tá na cobra coral/ Ô ô/ Num pedaço de paio/ A lé tá na marél Na lâmina de um punhal/ $\hat{O}$ ô/ Na luz, na escuridào.

Andar com fé eu vou/ Que a fé não costuma "faiá". (bis)

A fé tá na manhã/ A fé tá no anoitecer/ Ồ ô/ No calor do verão/ A fé tá viva e sãl A fé também tá pra morrer/ $\hat{O} \hat{o} /$ Triste na solidào.

Andar com fé cu vou/ Que a fé não costuma "faiâ". (bis)

Certo ou erralo até/ A fé vai onde quer que cu vál Ố $\hat{o}$ A pé ou de avião/ Mésmo a quem não temr lés A fé costuma acompanhar/ $\hat{O}$ ól Pelo sim pelo não.

Andar com lé eu vou/ Que a lé não costuma "faiá". (bis)

A maioria da população hrasileira confia em Jesus Cristo. As religiões predominantes são as cristãs e mesmo quem não freqüenta igrejas, acredita em seu poder. A letra de Jesus Cristo, de autoria de dois ídolos do movimento Jovem Guarda, gravada por Roberto Carlos em 1970, ilustra este fato, demonstrando que "Ele" pode ser o caminho. 


\section{JESUS CRISTO (Roberto Carlos/Erasmo Carlos)}

Refrão: Jesus Cristo, Jesus Cristo, Jesus Cristo eu estou aqui... (bis)

Olho pro céu e vejo una nuvem branca que vai passando/ Otho pra terra e vejo uma multidão que vai caminhando/ Como essa nuvem branca essa gente não sabe aonde vai/ Quem poderá dizer o caminho certo é vocề meu Pai (Refrão)

Toda essa multidão tem no peito amor e procura a paz / E apesar de tudo a esperança não se desfaz / Olhando a flor que nasce no chão daquele que tem amor/ Olho pro céu e sinto crescer a fé no meu Salvador

(Refrão)

Em cada esquina eu vejo o olhar perdido de um irmão/ Em busca do mesmo ben nessa direção caminhando vem/ É meu desejo ver aumentando sempre essa procissão/ Para que todos cantem com a mesma voz essa oração.

(Refrão)

A música a seguir, gravada em 1942 por Dalva de Oliveira (1920-1972), representa o canto do Angelus, que era tradicional no país quando, às seis horas da tarde, alto-falantes tocavam uma Ave-Maria. No período em que foi composta, a religião católica ainda se comportava como religião oficial do país. Entretanto, a letra a seguir, se enquadra mais naquelas que procuram elogiar a pobreza de quem mora nas favelas cariocas pois, ao se situarem nos morros, estariam mais perto do céu.

\section{AVE MARIA DO MORRO (Herivelto Martins)}

Barracão/ De zinco/ Sem telhado/ Sem pintura/ Lá no morro/ Barracão é bangalô.

Lá não existe/ Felicidade/ De arranha-céu/ Pois quem mora lá no mono/ Já vive pertinho do céu.

Tem alvorada/ Tem passarada/ Ao alvorecer/ Sinfonia de pardais/ Anunciando o anoitecer.

E o morro inteiro/ No fim do dia/ Reza uma prece/ A Ave Maria/ E o morro inteiro/ No fim do dia/ Reza uma prece/ A Ave Maria

Ave Maria/ Ave.... 
Os geógrafos especializados em religião estudam o espaço geográfico "através da análise do sagrado, desvendando sua ligação com a paisagem e com a linguagem codificada pelo homem religioso em sua vivência no espaço." (ROSENDAHL, 1998:134) Religião e paisagem constituem o núcleo da abordagem e o espaço sagrado tem uma relação íntima com o grupo religioso, grupo este que necessita se apoiar em um objeto, em uma parcela da realidade, que dê estabilidade a sua crença. "O segredo do sagrado confere poder aos especialistas religiosos, cabendo aos leigos, crentes e fiéis, a categoria de destituídos do capital religioso e excluídos do trabalho simbólico, pelo simples fato de que não possuem o conhecimento para o exercício desse poder sagrado." (ROSENDHAL, 2003:190) As imagens do espaço religioso são importantes na memória do grupo e o sentido dos aspectos do lugar possui, muitas vezes, significação somente aos crentes. Um espaço sagrado pode se estabelecer sem uma hierofania - palavra que vem do grego hierós, $a$, on = sagrado, divino, e de phaino $=$ brilhar, aparecer - mas não se mantém se ela não ocorrer, se não existirem milagres atribuídos ao patrono. As experiências do sagrado constituem um processo de mitificação do espaço geográfico. É o mito como presença viva ao fornecer modelos de comportamento ou conferir significados à existência humana. A exteriorização das crenças desempenha um papel significativo na coesão de grupos e também na configuração dos lugares, pois a religião é capaz de interferir nas formas de perceber e de estruturar espaços. "Edifícios da Igreja, propriedades, lugares sagrados, paróquias e dioceses são lugares separados por limites, dentro dos quais a autoridade e o acesso são controlados, constituindo-se em territórios." (ROSENDHAL, 1997:147)

Em um espaço considerado sagrado existem dois elementos fundamentais: o ponto fixo, no qual as formas espaciais cumprem funções diretamente associadas à hierofania, e o entorno, que possui "os elementos necessários ao crente para a realização de suas práticas e de seu roteiro devocional." (ROSENDHAL, 1997:122) É através de símbolos, mitos e ritos que o sagrado realiza a função de mediador entre os seres humanos e as divindades. Este sagrado é perceptível na organização espacial principalmente pelos impactos provocados pelos devotos naquele lugar. Ir ao encontro do local sagrado é chamado de peregrinar, verbo que, em latim, significa "viajar por lugares distantes, por países estrangeiros". Peregrinus é aquele "que viaja no estrangeiro, que vem do estrangeiro". (FARIA, 1992:400) Em um país católico como o Brasil, peregrinar é ir em romaria por lugares de devoção. Mas a natureza do ato está intimamente ligada a visitas a locais considerados sagrados, uma prática comum a várias religiões. Este lugar sacro não seria determinado pelos homens, mas revelado por um ente superior. Em cada espaço há formas simbólicas que o distingue dos lugares profanos ou de outros espaços sagrados, o que podemos ver tanto na Praça São Pedro, no Vaticano, quanto na Kaaba', em Meca, no Muro das Lamentações, em Jerusalém, no Ganges em Benarés, na cidade de Lhasa, para o lamaísmo, ou em Kyoto, para o xintoísmo. Se para os muçulmanos o ritual se reveste de obrigação, no catolicismo o movimento 
é mais voluntário e voltado para o cumprimento de promessas pessoais, geralmente associadas a dificuldades físicas e econômicas. Cabe lembrar que, para algumas religiões (como a ortodoxa grega), o ícone é mais importante que o lugar. Para muitos católicos, a vinda da imagem de Nossa Senhora Aparecida substitui a ida ao Santuário.

Os fatos religiosos que acabaram por caracterizar um lugar como sagrado ocorreram em um determinado momento histórico. A noção de tempo é diferente, pois cada vez que se visita o local existe um reencontro do mesmo tempo sagrado, que se manifesta, muitas vezes, há séculos, acrescido de aspectos mais modernos somente nos espaços profanos vinculados a este espaço sagrado.

Entretanto, a viagem do peregrino difere da do turista típico, mesmo daquele que visita locais sagrados. Posso ir ao Vaticano como peregrino ou como turista. Este último procura lazer, cultura, mais fascinado por Michelangelo do que pelo Papa; o peregrino também sai do cotidiano, mas pela via do sacrifício. O fazer sagrado (sacra facere) é associado a ritos de submissão a um ser superior e exige algum sacrifício físico; algum tipo de privação é da própria natureza desta migração. No santuário, o espaço do ritual, o ambiente adequado à manifestação religiosa, não há novidade ou estupefação pois os significados já são conhecidos e o encontrado é o esperado desde a partida. Há a satisfação do dever cumprido que, na maioria das vezes, é superior ao fato de ter visitado aquele dado lugar. O conforto espiritual do retorno é diferente da volta do simples turista.

Existe uma realidade na paisagem religiosa; ela é essencialmente visivel, porém, para explicá-la, é preciso apelar para os fatores invisíveis presentes nas práticas religiosas. Os romeiros realizam uma combinação de atividades religiosas que, pela sua repetição habitual, conferem uma fisionomia própria aos centros religiosos. Essas práticas religiosas possuem um roteiro mais ou menos preestabelecido na percepção hierárquica do peregrino de viver o sagrado no espaço e no tempo. (ROSENDAHL, 1997:136)

O peregrino (ou romeiro) típico é um consumidor do sagrado, pratica sua religiosidade no santuário (participando de missas e recebendo os sacramentos), depende dos "profissionais do sagrado", enquanto o turista - diferente até nos trajes - vivencia mais o espaço, a arquitetura do local, os aspectos mais gerais, e tem necessidade de documentar sua presença fotografando ou filmando. É possível distinguí-los inclusive pelo tipo de compra que fazem, embora existam "peregrinos turistas". Mas, se adotar a identificação acima, pode-se observar que nos santuários

\footnotetext{
' Em árabe: dado de jogar; designa a casa de forma cúbica. Kaaba é o edifício cúbico, no centro da Grande Mesquita, onde está encerrada a pedra negra (trazida a Abraão pelo anjo Gabriel), que é o ponto de orientação para os islâmicos quando rezam.
} 
brasileiros o fluxo de romeiros é muito maior que o de turistas; estes, muitas vezes, preferem visitar a manifestação do mesmo sagrado em países europeus.

Em primeiro lugar, é preciso caracterizar os diversos tipos de peregrinos, do fiel ao devoto em potencial. O peregrino se desloca para o lugar sagrado movido pela fé, visando pagar promessa, receber milagre ou fazer sacrifício; é o típico "consumidor de esperanças". O turista religioso conjuga lazer e fé, o prazer da viagem associado ao conhecimento de coisas e lugares novos. A maior potencialidade do turismo propriamente dito parece estar nos adeptos da "teologia da prosperidade", ou seja, naqueles que acreditam que o que podemos ser está representado pelas próprias posses. Para estes, o melhor lugar para o culto é o espaço no qual vivem, pois possui uma religiosidade relativamente autônoma. Eles podem ficar sós para rezar, para meditar, como fala a letra da canção Se eu quiser falar com Deus, escrita em 1980 por Gilberto Gil e lançada no mesmo ano em compacto simples. Observar que não se trata de um Deus determinado, mas do vazio pela sua ausência. da procura d'Ele para preencher este vazio.

\section{SE EU QUISER FALAR COM DEUS (Gilberto Gil)}

Se eu quiser falar com Deus/ Tenho que ficar a sós/ Tenho que apagar a luz/ Tenho que calar a voz/ Tenho que encontrar a paz/ Tenlo que folgar os nós/ Dos sapatos. da gravata/ Dos desejos, dos receios/ Tenho que esquecer a data/ Tenho que perder a conta/ Tenho que ter as mãos vazias/ Ter a alma e o corpo nus.

Se eu quiser falar com Deus/ Tenho que aceitar a dor/ Tenho que comer o pão/ Que o diabo amassou/ Tenho que virar um cão/ Tenho que lamber o chão/ Dos palácios. dos custelos/ Suntuosos do meu sonho/ Tenho que me virar tristonho/ Tenho que me achar medonho/ E apesar de um mal tamanho/ Alegrar mea coraçáo.

Se cu quiser falar com Deus/ Tenho que me aventurar/ Tenho que subir aos céus/ Sen cordas pra segurar/ Tenho que dizer adeus/ Dalr as costas, caminhar/ Decidido, pela estrada/ Que ao findar vai dar em nada' Nada, nada, nada. nada/ Nada, nada, mada, nada/ Nada, nada, nada. nada/ Do que eu pensava encontrar.

As cidades brasileiras normalmente possuem um santo - ou uma santa -padroeiro e. às vezes, se reza uma novena nos dias anteriores à data da festa. A novena pode ser também para a solicitação de chuvas ou por outras razões. A canção a seguir, gravada por Geraldo Azevedo, Vital Farias e Xangai, em 1984, retrata um pouco o esquecimento provocado, muitas vezes, por estas práticas, em relação ao que está ocorrendo no mundo. 


\section{NOVENA (Geraldo Azevedo/ Marcus Vinicius)}

Nas horas de Deus amém/ Padre, Filho. Espírito Santo/ Essál é a primeira cantigal Que nessal cistal eu canto.

Sei que são nove dias nove penas/ Encuanto a espera aument:/ O mundo se faz esquecido/ Na terra dos homens/ De luzes coloridas.

Enquanto a família reza novenad As notícias que montam cavalos ligeiros/ Vão tomando todo o mundo/ E na casa do lar/ Esquecidos ficam todos longe de saber O que foi que aconteceu/E ali ninguém percebeu/ Tanta pedra de amor cair/ Tanta gente se partir/ No azul dessa incrivel dor/ Enquanto a família rezal alguém/ Segue $c$ novena/ No abismo de preces repetidas/ No sossego de una agonia sem fïm.

Enquanto a família reza novena/ Nove dias se passaram marcados/ Sem tempo, sem nada e sem fim/ No meio do mundo, do medo/ E de mim desespedaçado em tanto verso/ Então de oraçòes a sala se faz/ E lá fora se esquece a paz/ Una bomba explodiu por lá/ Sobre os olhos do meu bem/ E assim me mala lambém/ Enquanto a novena chega ao fimi Bandas. bandeiras/ Benditos passando pela vida/ E a novena se perde esquecida de nós.

Nas horas de Deus amém/ Padre. Filho, Expirito Santo/ Exat a a primeira cantigal Que nessa casa eu canto.

O dia do santo padroeiro è um feriado municipal a antigamente celebravam esta data com procissoes, acompanhadas de bandas e se sollavam foguetes para comemorar. Hoje ainda são celebradas, mas estas datas perderam a participação que possuíam. Capiba compôs a música Festa da Padroeira que retrata muito bem como eram esses dias no passado. Foi regravada por Antonio Nóbrega no CD Pernambuco falando para o mumdo em 1999, sendo a faixal de n. 02 deste compact disc.

\section{FESTA DA PADROEIRA (Capiba)}

Quando a passarada/ Passa en revoada/ E a charanga vai tocando,/ E sem querer eu vou cantando.

É dia de festa,/ Dia de handerira/ Bandeira de novena,/ Novena da padroeira. Quando estou sozinho/ E ouço csse dobrado/ Que recordaçóes das moças do sobrado .../ Vejo a meninada/ Pulando e gritando,/ E o fogueteiro os seus foguetes espoucando.

Era chique ver/ Todo mundo na rua a vibrar/ E, a passear, a charrete,/ $O$ fordeco, a mulher, o coronel e o seu chofer/ Em direção à igreja, / Onde o povo cantava/ Em louvor à santa/ Quando a festa começava. 
Os mapas e a ambição trouxeram para Pindorama os colonizadores lusitanos e os missionários jesuítas. A "cristandade colonial" aqui organizada foi fruto direto da Contra-Reforma ${ }^{2}$, um catolicismo de combate aos infiéis que foi aplicado a uma região que não havia tido o passado que provocara aquele concílio. E foi posto em prática por uma Igreja ligada ao despotismo português e por portugueses que se acreditavam escolhidos por Deus para dominar, em nome da fé, as várias partes do mundo; uma espécie de "Destino Manifesto" lusitano. Todos por aqui tinham que ser católicos, o que também significava ser submisso à Coroa. Não tínhamos burgos e heresias, nem islâmicos ou protestantes; sem essas grandes ameaças, o catolicismo passou a ser dominante, se transformando mais em um "estilo cultural" que em uma opção de fé.

Durante os séculos XVII e XVIII, as romarias, principalmente no interior do país, nasciam espontaneamente da piedade popular e se desenvolviam com ampla liberdade de expressão por parte do povo. As devoções surgem do povo. As imagens eram encontradas por pescadores, índios, aventureiros, e o aspecto milagroso da aparição da imagem evidenciava a vontade divina que escolhera esse lugar para ser destinado ao culto. (ROSENDAHL, 1997, p. 143)

Durante o século XVII ocorreu uma expansão de santuários em razão da grande corrente migratória, principalmente de portugueses, em direção às regiões mineiras. Entretanto, esta expansão se caracterizou pela ausência das ordens religiosas que evangelizaram o litoral brasileiro, sendo um movimento mais leigo que clerical. "Os santuários que surgem neste período representam uma tentativa popular de valorização da fé e da moral católicas, em oposição aos males trazidos pelo ouro." (ROSENDAHL, 1997:144) E neles predominava o catolicismo popular, e não o oficial, com um conjunto de representações e de práticas que representavam o sincretismo dos símbolos religiosos introduzidos pelos portugueses e alguns brasilíndios e africanos.

Enquanto a Coroa se comprometia com a difusão e manutenção do catolicismo como religião oficial, a hierarquia eclesiástica se comprometia a fortalecer o projeto colonial. Disso deriva sua atitude de incutir a obrigação de obediência à Coroa, aportuguesando a própria religião. A liturgia européia foi para cá transplantada, as cerimônias eram realizadas na língua latina e para uma população que não a entendia e que era analfabeta, o que a impedia de ler a Bíblia - o que a Igreja Católica também não estimulava. A reação possível frente a estas imposições foi o sincretismo religioso.

O sincretismo religioso é mais marcante nas regiões que utilizaram a mãode-obra escrava negra. Compelidos a praticar seus cultos clandestinamente, os

\footnotetext{
${ }^{2}$ A Reforma Protestante ocorreu em 1517, fruto dos abusos da Igreja Católica e da necessidade de mudanças ideológicas em razão das alterações sócio-econômicas e políticas ocorridas na Europa. $\mathrm{O}$ Concílio de Trento (1545-1563) - a Contra Reforma - reforçou a autoridade papal, manteve a doutrina tradicional, restabeleceu a disciplina na Igreja, criou um catecismo e os seminários religiosos.
} 
fiéis ligados principalmente ao candomblé e à umbanda, escondiam sua opção religiosa, declaravam-se católicos, participavam de cerimônias, mas passaram a associar os orixás aos santos católicos. Como Iemanjá associada a Nossa Senhora da Conceição, Iansã a Santa Bárbara, assim como festas de São Benedito com ternos de congo percorrendo as ruas. Na Bahia, por exemplo, as atividades religiosas marcadas pelo sincretismo transformaram-se hoje até mesmo em atrações turísticas.

$\mathrm{Se}$ as outras religiões eram marginalizadas, isto era mais marcante com as de origem negra africana. Essa foi uma das razões da grande repercussão que teve o lançamento em 1966 do disco "Os afro-sambas", com músicas de Baden Powell (1937-2000) e letras do branco Vinícius de Moraes (1913-1980). Foram oito músicas com a temática ligada ao candomblé e que transformaram este disco em um clássico da MPB. Daí a colocação, na sequiência, de quatro letras deste LP, dada a importância do fato, a presença deste sincretismo ao qual fizemos referência e ao passado de marginalização, pois este tema - apesar da grande presença de negros em composições da MPB - estava ausente da vida de grande parte dos brasileiros. Alguns comentários feitos antes das letras foram baseados no texto de Vinícius de Moraes na contracapa deste LP.

A primeira letra, de Canto de Ossanha, nos mostra uma visão positiva, de não se recuar a enfrentar os problemas do amor e da vida, com expressões típicas (saravá, Xangô, Orixá) de crenças de origem africana.

\section{CANTO DE OSSANHA (Baden Powell/Ninicius de Moraes)}

O homem que diz "dou" não dá, porque quem dá mesmo não diz/ O homem que diz "vou" não vai, porque quando foi já não quis/ O homem que diz "sou" não é, porque quem é mesmo é "não sou"/ O homem que diz "tô" não tá, porque ninguém tá quando quer/ Coitado do homem que cai no canto de Ossanha, traidor/ Coitado do homem que vai atrás de mandinga de amor Vai, vai, vai, vai, não vou/ Vai, vai, vai, vai, não vou/ Vai, vai, vai, vai, não vou/ Vai. vai, vai, vai, não vou/ Que eu não sou ninguém de ir em conversa de esquecer/ $A$ tristeza de um amor que passou/ Não, eu só vou se for pra ver uma estrela aparecer/ Na manhã de um novo amor

Amigo senhor, saravá, Xangô me mandou lhe dizer/ Se é canto de Ossanha, não vá, que muito vai se arrepender/ Pergunte ao seu Orixá, o amor só é bom se doer/ Pergunte ao seu Orixá, o amor só é bom se doer.

Vai, vai, vai, vai, amar/ Vai, vai, vai, sofrer/Vai, vai, vai, vai, chorar/ Vai, vai, vai, dizer/ Que eu não sou ninguém de ir em conversa de esquecer/ $A$ tristeza de um amor que passou/ Não, eu só vou se for pra ver uma estrela aparecer/ Na manhã de um amor. 
A música seguinte, Camto de Xangô, se for possível ouvi-la, observar a estrutura rítmica, verificar-se-á que é praticamente candomblé. Nesta canção Xangô ogodô, o orixá velho, conta seu passado e adverte Xangô jovem a superar seu primeiro fracasso amoroso e a amar sem medo.

\section{CANTO DE XANGô (Baden Powell/Vinícius de Moraes)}

Eu vim de bem longe/ Eu vim, nem sei mais de onde é que eu vim/Sou filho de Rej/ Muito lutei pra ser o que eu sou/ Eu sou negro de cor/ Mas tudo é só o amor em mim/ Tudo é só o amor para mim/ Xangô Aggodô/ Hoje é tempo de amor/ Hoje é tempo de dor, èm mim/ Xangồ Agodô.

Salve, Xangó, mea Rei Senhor/ Salve, meu Orixá/ Tem setc cores sua cor/ Sete dias para gente amar.

Mas amar é sofrer/ Mas amar é morrer de doy/ Xangô, meu Senhor, saravá!/ Me faça sofrer/ Ah, me faça morrer/ Ah, me faça morrer de amar/ Xangô, meu Senhor, saravá/ Xangô Agodô

No início da próxima letra, a Rainha do Mar (Iemanjá, sereja neta de Oxum) anuncia a sua presença e cativa os homens para uma "boda sem sexo".

\section{CANTO DE YEMANJÁ (Baden Powell/Vinícius de Moraes)}

Iemanjá. Iemanjá/ lemanjá é dona Janaína que vem/ lemanjá, Iemanjá/ Iemanjá é muita tristeza que vem.

Vem do luar no céu/ Vem do luar/ No mar coberto de flor, meu bem/ De Iemanjá/ De Jemanjáa a cantar o amor/ E a se mirar/ Na laá triste no céu. meu bem/ Triste no mar. Se você quiser amar/ Se você quiser amor/ Vem comigo a Salvador/ Para ouvir Iemanjá.

A cantar, na maré que vail E na maré que vem/ Do fim, mais do fim, do mar/ Bem mais além/ Ben mais além do que o fïm do mar/ Bem mais além

$\mathrm{Na}$ letra a seguir houve uma tentativa de dar um sentido ao canto original do "caboclo" (Olô pandeiro, Olô viola). Procurou-se retratar um conflito entre amor e sexo, cuja farpa é o ciúme, no qual o elemento "macho" (pandeiro) repudia a entrada do "caboclo" Pedra Preta (o outro), já como divindade de pai-de-santo capaz de arrastar a "fêmea" (a viola) para um mundo mais místico. Pedra Preta os incitava a não fugirem de seu destino (... pandeiro tem que pandeirar/viola tem que violar). Quando o galo cantou fora de hora, o pandeiro, derrotado, partiu. Pedra Preta foi colocado como um elemento perturbador de um eterno conflito da vida. 


\section{CANTO dO CABOClo DA PEDRA PRETA (Baden Powell/Vinícius de Moraes)}

Pandeiro não quer que eu sambe aqui/ Viola não quer que eu vá embora

Olô pandeiro, Olô viola/ Olô pandeiro, Olô viola

Pandeiro quando toca faz. Pedra-Preta chegar/ Viola quando toca faz Pedra-Preta sambar

O pandeiro diz: Pedra-Prela não samba aqui, não/ A viola diz: Pedra-Preta não sai daqui, não

Pedra-Preta diz: Pandeiro tem que pandeirar/ Pedra-Preta diz: Viola tem que violar O galo no terreiro fora de hora cantou/ Pandeiro foi-se embora e Pedra-Preta gritou: Olô pandeiro, Olô violà/ Olô pandeiro. Olô viola

Um compositor baiano, no qual a presença de crenças africanas é constante, chama-se Dorival Caymmi. A mistura de crenças católicas e das trazidas da África cáacteriza boa parte de suas composições. Um dos exemplos que pode ser citado é a letra de Promessa de Pescador, na qual ele pede proteção a Iemanjá para o filho pescador.

\section{PROMESSA DE PESCADOR (Dorival Caymmi)}

Ê,E.Ê/ A alodê Yemanjá odoiál Senhora que é das águas/ Tome conta de meu filho/ Que eu também já fui do mar.

Hoje tô véio acabado/ Nem no remo sei pegar/ Tome conta de meu filho/ Que eu também já fui do mar/ $\hat{E}, \hat{E}, \hat{E}$

A alodê Yemanjá odoiá/ Quando chegar seu dia/ Pescador véio promete/ Pescador vai me levar/ Um presente bem bonito/ Para Dona Yemanjá/ Filho dele é quem carrega/ Desde terra até o mar.

O sincretismo religioso permite a ocorrência no país de festas católicas onde há a presença de praticantes de outras religiões; ou de festas de Umbanda em escadarias de igrejas católicas, com a presença de muitos católicos. Como, por exemplo, a lavagem, em janeiro, das escadarias da Igreja do Senhor do Bonfim? em Salvador (BA); a festá do Círio de Nazaré, realizada em outubro na cidade de

\footnotetext{
2O Hino ao Senhor do Bonfim da Bahia (de João Antonio Wanderlei e Petion de Vilar) foi gravado no LP Tropicália on Panis et Circensis, de 1968, um disco-manifesto do movinento tropicalista. Com arranjo de Rogério Duprat e cantado por Caetano Veloso. Gilberto Gil. Mutantes. Gal Costa e coro. é a faixal 6 do lado B.
} 
Belém (PA), ilustra a primeira citação. A procissão do Círio foi introduzida pelos portugueses em Belém em 1793 e também ocorre em três outras localidades amazônicas: Viga (PA), Marabá (PA) e Macapá (AP); no ano de 2.000, reuniu cerca de 1,5 milhão de pessoas. ${ }^{4}$

No Sertão Nordestino, a religião católica praticada também possuía um profundo sincretismo com tradições brasilíndias e africanas. As pressões para a centralização do poder, religioso ocorridas na segunda metade do século XIX - a busca pela Igreja da "romanização" do culto no país -, ou seja, a tentativa de retomada do controle da religiosidade popular, foi uma das inúmeras causas do Levante de Canudos (1896-1897) no Sertão baiano. Antonio Conselheiro permanece presente no imaginário e na literatura de cordel. Também marcante nas invocações e objeto de intensa devoção popular é a figura do padre e político cearense Cícero Romão Batista (1844-1934) que foi, em 1872, nomeado vigário de Juazeiro do Norte (CE). Após ser suspenso de ordens pelas autoridades eclesiásticas, erigiu uma igreja e se transformou em uma importante liderança. Por causa dos milagres atribuídos a "Padim Ciço", o município de Juazeiro do Norte - onde foi erguida uma estátua - se tornou um importante centro de peregrinação.

Para ilustrar essa crença, temos a letra de Padre Cícero, de Tim Maia e de Cassiano, gravada por Tim Maia em 1970. Ela afirmava que ele morreu pobre, o que não é verdadeiro, mas realça o mito criado a seu respeito.

\section{PADRE CÍCERo (Tim Maia/Cassiano)}

No sertão do mapa, nasce um homem pobre/ Porém muito jovem, porém muito jovem/ Todo mundo vai saber, quem ele é/ Este homem estuda, mesmo sem ajuda/ Se formou primeiro e no Juazeiro/ Todo mundo respeitou, padre Cícero/ Padre Cícero, padre Cícero, padre Cícero.

Daí então tudo mudou, de reverendo a lutador/ Desperta ódio e amor. passaram anos pra saber/ Se era amor ou mal, mas ninguém/ Até hoje afirmou/ Era um triste dia, pois alguém jazia/ Cego, surdo e pobre, cego, surdo e pobre/ Desse jeito faleceu, padre Cícero/ Padre Cícero, padre Cícero. Padim Ciço

\footnotetext{
${ }^{4}$ Uma pesquisa realizada em 1999 constatou que $98 \%$ dos participantes eram paraenses, mas que somente $51.5 \%$ eram católicos; o segundo grupo, com $28,4 \%$, era de evangélicos e estes, normalmente, não cultuam imagens. ( $F S P, 09 / 10 / 2.000$, p. A5)
} 
Diferente de outros "místicos", Padim Ciço era ligado "à lei e à ordem"; amigo dos coronéis, foi prefeito de Juazeiro do Norte (1911) e até vice-presidente do Ceará. Rege a lenda que, em 1889, uma hóstia havia se transformado em sangue no momento em que ele dava a comunhão, o que o fez ganhar a fama de milagreiro. Defensor da ordem oligárquica, foi na verdade um coronel de batina; e ficou rico: "no seu testamento constavam cinco fazendas, trinta sítios e mais de quinze prédios, inclusive o da cadeia de Juazeiro ..." (RIBEIRO, 1988:35).

Euclides da Cunha, em "Os Sertões", ao retratar - a seu modo - o sertanejo nordestino, afirmou que sua religião era como ele: mestiça. Que estava "na fase religiosa de um monoteísmo incompreendido, eivado de misticismo extravagante, em que se rebate o fetichismo do índio e do africano." (CUNHA, 1982:107) Na mestiçagem de crenças estavam "o antropismo do selvagem, o animismo do africano e [...] o próprio aspecto emocional da raça superior, na época do descobrimento e da colonização. [...] Nem lhe falta [...] o misticismo político do 'sebastianismo'." (CUNHA, 1982:108-109) Ao escrever sobre Bom Jesus da Lapa (BA), que chamava de "Meca dos Sertanejos", descreveu as características da gruta que se tornou um local de romarias.

Segundo Riolando Azzi, os

[...] centros de devoção e romarias populares constituem ao longo da história do Brasil o lugar de maior expressão coletiva na religião popular. Em contraposição à religião oficial, controlada pelo poder político e eclesiástico na época colonial e imperial, a fé católica expressa nas romarias representa uma dimensão de liberdade e autonomia do povo. (apud CAVALCANTE, 1998:148)

Nos santuários populares há locais que comprovam a veracidade da epígrafe latina Votum fecit gratiam accepit ("Fez um voto e recebeu a graça"), que são aquelas salas com objetos (ex-votos) representando partes do corpo humano, fotos, óculos, cabelos (que cresceram no período da promessa), muletas etc. É o testemunho de que a promessa (voto) resultou em milagre (ex-voto). $\mathrm{O}$ autor de "Os Sertões" descreveu o sentimento da promessa e dos ex-votos como um elemento importante da fé sertaneja, mesmo daquele sertanejo que ele considerava um bandido ${ }^{6}$ :

\footnotetext{
${ }^{5}$ Ele também sempre foi muito presente na literatura de cordel; o texto a seguir é um exemplo: Vou pedi meu Padim Ciço/Vou pedi com devoção/ Padim Ciço neste mundo/ É a nossa sarvação/ Cura espinhola caida/ Sabe fazê oração/ Tira demonho do corpo/ Afugenta tentação. Vou pedi meu Padim Ciço/ Pra minha água reza/ Tirá quebranto da égua/ Outras mazela tirál Vou pedi meu Padim Ciço/ Pra minha égua benzel Ela anda descadeirada/ D'oio direito não vê. (RIBEIRO, 1988:34)

"No texto citado, clavinoteiro (clavina = carabina) significa "bandido sertanejo".
} 
[...] entre as dádivas que jazem em considerável cópia no chão e às paredes do estranho templo, o visitante observa, de par com as imagens e as relíquias, um traço sombrio de religiosidade singular: facas e espingardas. O clavinoteiro ali entra, contrito, descoberto. Traz à mão o chapéu de couro, e a arma à bandoleira. Tomba genuflexo, a fronte abatida sobre o chão úmido do calcário transudante ... E reza. Sonda longo tempo, batendo no peito, as velhas culpas. Ao cabo cumpre devotamente a 'promessa' que fizera para que lhe fosse favorável o último conflito que travara: entrega ao Bom Jesus o trabuco famoso, tendo na coronha alguns talhos de canivete lembrando o número de mortes cometidas. Sai desapertado de remorsos, feliz pelo tributo que rendeu. Amatula-se de novo à quadrilha. Reata a vida temerosa. (CUNHA, 1982:163-164)

Estas breves observações intentam demonstrar que existem vários catolicismos no Brasil ${ }^{7}$ e que suas manifestaçōes culturais são importantes para debater os espaços criados pela religião no país. Isso, aliás, pode valer para outros países e outras religiões. Diversidade de organizações paroquiais, de posições ideológicas, de classes sociais, de influências culturais, leva a uma diversidade de ritos e crenças. A religião vivida pelo povo nem sempre é a das autoridades eclesiásticas. E, talvez, a obediência cega do fiel às normas litúrgicas impediria a variedade de crenças que, do ponto de vista cultural, é muito mais interessante. Se o comportamento dos católicos sempre correspondesse ao que é próprio do catolicismo, se não houvesse uma concentração das atenções nos "santos", se no Brasil a prática católica não possuísse fontes religiosas européias, africanas e brasilíndias, se muitas das tradições religiosas não tivessem se convertido em mercadorias a serem consumidas, o interesse turístico sobre o tema também seria menor.

Esta diversidade - ao lado da presença eclesiástica - fez com que certas datas tivessem características diferentes. Mas festas datadas pela Igreja Católica têm presença em letras da MPB. Por exemplo, a festa de Corpus Christi, na qual em alguns municípios, para a passagem da procissão, se colocam flores e pó de madeira nas ruas, com arranjos coloridos sobre o tema. Relata também isso a letra de Paixão e fé, de Tavinho Moura e Fernando Brant, que foi gravada por Milton Nascimento, com a participação dos Canarinhos de Petrópolis, em 1978.

\footnotetext{
${ }^{7}$ Às vezes, isso ocorre em uma mesma cidade. Ver, por exemplo, o caso de Itapira (SP), tema do livro "Os catolicismos brasileiros", de Lemos Filho (1996).
} 


\section{PAIXÃO E FÉ (Tavinho Moura/ Fernando Brant)}

Já bate o sino, bate na catedral/ E o som penetra todos os portais/ A igreja está chamando seus fiéis/ Para rezar por seu Senhor/ Para cantar a ressurreição.

E sai o povo pelas ruas a cobrir/ De areia e flores as pedras do chão/ Nas varandas vejo as moças e os lençóis/ Enquanto passa a procissão/ Louvando as coisas da fé. Velejar, velejei/ No mar do Senhor/Lá eu vi a fé e a paixão/ Lá eu vi a agonia da barca dos homens. (bis)

Já bate o sino, bate no coração/ E o povo põe de lado a sua dor/ Pelas ruas capistranas de toda cor/Esquece a sua paixão/ Para viver a do Senhor.

Velejar, velejei/ No mar do Senhor/ Lá eu vi a fé e a paixâo/ Lá eu vi a agonia da barca dos homens. (bis)

Sobre outra festa religiosa, o Natal, existe uma música no CD Terra dos Sonhos, de Almir Sater, gravado em 1994 e distribuído pela Velas (é a faixa n. 7). Fala do significado da festa e do que ela representa.

\section{JESUS MENINO (Geraldo Roca)}

Hoje viemos p'ra festejar/ Jesus menino/ Não lamentamos/ Vamos dançar, beber o vinho/ Homens e mulheres que somos/ Comemoramos/ Foi p'ro seu aniversário/ Que saímos/ Celebraremos.

Então juntamos/ Filhos e pais e tios e primos/ Desejos que não consentimos/ Nos confessamos/ Então homens, mulheres que somos/ Desejaremos.

Porque viemos/ P'ra festejar Jesus menino/ Não navegamos/ Vamos deixar baixar os remos/ Logo será bom retomar/ Os nossos rumos/ Então homens/ Mulheres que somos/ Navegaremos.

Existe também outra sobre uma figura muito ligada ao Natal: Papai Noel. É a letra de Boas Festas, marcha natalina feita por Assis Valente (1911-1958) em dezembro de 1932 e gravada no ano seguinte. Obteve um grande sucesso; mas foi composta em um momento de tristeza e solidão.

\section{BOAS FESTAS (Assis Valente)}

Anoiteceu/ o sino gemeu/ a gente ficou/feliz a rezar./ Papai Noel/ vê se você tem/ a felicidade/ pra você me dar.

Eu pensei que todo mundo/ fosse filho de Papai Noel./ Bem assim felicidade/ Eu pensei que fosse uma/ brincadeira de papel./ Já faz tempo que pedi/ mas o meu Papai Noel não vem/ com certeza já morreu/ ou então felicidade/ é brinquedo que não tem. 
Em 1975, em um disco de encontro entre Gilberto Gil e Jorge Ben, a primeira música homenageava o padroeiro dos motoristas - São Cristóvão - que, segundo a crença, teria ajudado um menino - que seria Jesus - a atravessar um rio. ${ }^{8}$

\section{MEU GLORIOSO SÃO CRISTÓVÃo (Jorge Ben)}

Meu glorioso São Cristóvão/ Meu glorioso mártir/ Meu glorioso mártir/ Portador de Cristo/ Intercedei por nós/ Nos flagelos, terremotos/Incêndios, inundações/ Nas viagens de terra/ Subterrâneo, mar e ar/ Livrai-nos do pecado/ Da perdição/ Conduzimo-nos a Deus/ Até o porto seguro/ Da felicidade eterna/ Imploramos por Jesus Cristo/ Que conduziste nos ombros./ Amém

No Brasil, ainda existem poucos estudos abordando a relação entre Geografia e Religião, o que é uma grande falha. A religião é um fenômeno cultural e, portanto, ocorre espacialmente. $\mathrm{O}$ marco inicial de muitas cidades brasileiras foi uma capela, um terreno doado a um santo (patrimônio religioso), ao redor do qual foi construído o espaço profano. E existem muitas localidades que giram ao redor do espaço sagrado. O processo de ocupação do espaço brasileiro, "feito em etapas e valorizando áreas em momentos distintos, permitiu que o catolicismo no Brasil assumisse características próprias, bastante distintas do catolicismo europeu." (ROSENDAHL, 1996:37) A falta de sacerdotes, o isolamento de diversas áreas, a atuação de rezadores(as), beatos(as) e outros, entre diversas razões, caracterizaram, no catolicismo popular, a relação direta entre o crente e o santo, sem a intermediação institucional entre eles. Esta individualização da relação com o sagrado acabou dando ao praticante da fé uma independência nas decisões sobre matéria religiosa. Rezas, promessas e romarias acabaram sendo centradas nos santos (canonizados ou não), nos diversos títulos devocionais dados a Jesus ou a Maria, a lendas e até a almas às quais foram atribuídos milagres, estimulando visitas a cemitérios. Por exemplo, na cidade de Itapira (SP), a capela de Santa Cruz passou a se chamar capela Santa Cruz da Mão Aparecida ou Igreja da Mãozinha, uma devoção popular que se iniciou em 1906 quando um antigo escravo chamado Nicolau, um leproso que vivia de esmolas,

[...] foi encontrado morto, sendo enterrado no próprio rancho que foi queimado. Conta-se que depois de alguns dias começou a brotar, sobre o local em que o corpo fora enterrado, um cogumelo em forma de uma mão encarquilhada e voltada para cima. [...I Aos poucos, foi-se formando um culto organizado, com ritos e agentes populares, sem missa e sem padre. (LEMOS FILHO, 1996:53)

\footnotetext{
${ }^{8}$ Pode-se também utilizar como ilustração a letra da música feita por Gilberto Gil e Milton Nascimento em homenagem ao patrono da cidade do Rio de Janeiro, cognominada Sebastian. Ela se encontra no CD Milton \& Gil (Rio de Janeiro: WEA, p2000); é a faixa de n. 01
} 
No Brasil, portanto, se reza por diversas razões, inclusive pela amada; na letra a seguir uma canção de 1965 que solicita ao santo para trazer o seu amor.

REZA (Edu Lobo/ Ruy Guerra)

Por amor andei, já/ Tanto chão e mar/ Senhor, já nem sei/ Se o amor não é mais/ Bastante pra vencer/ Eu já sei o que vou fazer/ Meu Senhor, uma oração/ Vou cantar para ver se vai valer/ Laia, ladaia, sabatana, Ave Maria/ Laia, ladaia, sabatana, Ave Maria

Ó meu santo defensor/ Traga o meu amor? Laia, ladaia, sabatana, Ave Maria/ Laia, ladaia, sabatana, Ave Maria/ Se é fraca a oração/ Mil vezes cantarei/ Laia, ladaia, sabatana, Ave Maria/ Laia, ladaia, sabatana, Ave Maria.

Decorrente de nosso processo histórico, existe no país um conjunto de crenças e práticas do sagrado "que se constitui em um saber oral, um repertório de crenças e ritos recriados na memória coletiva popular." (LEMOS FILHO, 1996:53) E o catolicismo romano, assim como o islamismo, incentiva as peregrinações; não é preciso ir a Roma - origem do termo romaria - mas, para muitos, é fundamental a visita ao santuário de sua devoção. As religiões cristãs denominadas protestantes não fazem da peregrinação um componente essencial da prática religiosa. Temos, no país, diversas cidades-santuário, cujas funções urbanas estão essencialmente ligadas aos peregrinos, ou seja, que possuem uma peculiar organização funcional e social do espaço, fazendo das mesmas um objeto importante no estudo geográfico das cidades e, atualmente, em um componente importante da análise geográfica do turismo.

Algumas são menos importantes sob este aspecto por se constituírem "cidades de fim-de-semana" ou "cidades da semana-de-festa", conforme a periodicidade do fluxo de peregrinos. É o caso de alguns santuários analisados por Rosendahl (1993; 1995), como o Santuário de Jesus Crucificado em Porto das Caixas (na Baixada Fluminense), que recebia, em média, 2 mil pessoas a cada fimde-semana; a festa dedicada a Nossa Senhora d'Abadia do Muquém, no povoado de Muquém (Distrito do município de Niquelândia, a $447 \mathrm{~km}$ ao norte da capital de Goiás), entre os dias 5 e 15 de agosto, quando o povoado de 200 habitantes chegava a receber 60 mil romeiros; e a festa (de 5 a 14 de setembro) em louvor a uma milagrosa cruz de madeira deixada por um beato na igreja da cidade de Santa Cruz dos Milagres (no Piauí, 167 km a sudeste da capital), que via, neste período, sua população de 1.800 habitantes ampliada para 30 mil. $^{9}$

\footnotetext{
${ }^{9}$ Escreveu Rosendahl sobre este povoado: "O espaço profano, na parte mais baixa do terreno, é o espaço destinado ao comércio e ao lazer, numa espetacular mescla entre cerimônia religiosa e atividades profanas. A missa, a procissão e o sermão do padre representam a marca do sagrado oficial. A dança, as freqüentes bebedeiras e as brigas testemunham o profano." (ROSENDAHL, 1997:131-132)
} 
Mas outras, como Aparecida do Norte (SP), possuem um fluxo permanente e uma vida urbana voltada para isso. Resguardadas as diferenças, semelhante ao que ocorre em cidades-santuário de magnitude internacional, como a francesa Lourdes e a saudita Meca. A grandeza dos números apresentados pela maior basílica mariana do planeta não foi acompanhada por mudanças significativas na infra-estrutura da cidade, que permaneceu muito limitada para a demanda existente. Talvez o fato de serem visitadas por "turistas de um dia" e, ainda por cima, pobres, incapazes de consumo expressivo, ajuda a explicar o pouco interesse nos cursos de Turismo por estes locais.

O que torna um espaço sagrado é a manifestação de algo diferente da realidade cotidiana e essa hierofania pode se dar em um objeto qualquer ou em uma pessoa, demarcando o espaço como sagrado e revestindo-o de simbolismo. Quem demarca e diferencia este espaço é o crente, é ele que estabelece o que é sagrado e o que é profano. "A palavra profano etimologicamente implica a idéia de localização: o prefixo grego 'pro' significa 'em frente de', e 'fano' significa 'templo sagrado'." (ROSENDAHL, 1995:56) Profano é o espaço ao redor do espaço sagrado e, neste caso, é este último que possibilita a existência do primeiro. Portanto. o sagrado deve ser reconhecido como um elemento de produção do espaço. Algumas formas que simbolizam o sagrado são mais "resistentes" ao tempo, permanecendo com o significado enquanto seu entorno tem formas modificadas materialmente ou, quando não, se transformaram em "rugosidades". No sentido dado por Milton Santos, rugosidades são objetos do passado que permanecem e servem ao presente; existiram como significado e se comportam como um traço de união com os novos significados da vida social.

As rugosidades são o espaço construído, o tempo histórico que se transformou em paisagem. incorporado ao espaço. [...] nos oferecem [...] restos de uma divisão de trabalho internacional, manifestada localmente por combinações particulares do capital, das técnicas e do trabalho utilizados. [...] $O$ modo de produção que, [...] cria formas espaciais fixas, pode desaparecer - e isto é freqüente - sem que tais formas fixas desapareçam. (SANTOS, 1978:138)

Estas formas espaciais, ainda que hoje com uma nova função, são importantes para o turismo cultural, pois constituem a presença do passado. Mas o termo, em nossa opinião, não deve ser aplicado a símbolos sagrados, dada a permanência de significado e função. O Muro das Lamentações, em Jerusalém, não passa de uma velha construção; mas, para os judeus, possui uma mesma e importante significação há tempos. Aliás, a velha Jerusalém, a principal hierópolis do mundo, é uma das cidades mais difíceis de se entender e de se propor mudanças, pois ali cada rocha, túmulo, casa ou rua possui um significado para uma das três grandes religiões monoteístas do mundo.

Em centros religiosos populares, não controlados pelos centros hierárquicos religiosos, a demanda oscila, podendo diminuir com a laicização da sociedade e 
mudanças comportamentais religiosas. Em períodos de crises econômicas e sociais, em épocas de transição, os deslocamentos para estes centros tendem a ser mais intensos. É perigoso extrapolar para outras localidades; entretanto, como referência, pode-se citar um dos resultados do estudo de Zeny Rosendahl sobre Porto das Caixas (RJ), no qual agrupou "as promessas em três grupos que definem o "triângulo das necessidades'. No seu ápice está a saúde; num dos vértices da base, o trabalho, o emprego e os problemas de moradia; do outro lado da base, estão a formação da família, o amor, e a harmonia no lar". (ROSENDAHL, 1995:62)

Nos pequenos centros é difícil o planejamento da atividade, até porque muitos são de "peregrinos de um dia" e restritos a determinados períodos, o que restringe a implantação de uma rede hoteleira, por exemplo. Mesmo em cidades-santuário (hierópolis), como Aparecida do Norte (SP), a melhoria dos transportes acabou por permitir estadas menores. Mas a presença constante de romeiros está garantida enquanto as práticas de visitar a imagem e "pagar" promessas constituírem uma devoção comum. Visita-se um santuário, em geral, para garantir a aliança feita entre o fiel e seu santo-padrinho (o santo protege o devoto nesta vida e o crente lhe presta os cultos específicos) ou para cumprir a parte de uma relação contratual estabelecida com vistas a uma graça definida, desde que o santo tenha cumprido a sua parte. "É um ato de culto que tende a reduzir a religiosidade ética a uma norma estritamente formalista do do ut des." (ROSENDHAL, 1995:61) A expressão do ut des foi usada por Max Weber e, segundo Rosendahl (1993; 1995), simboliza o "toma lá da cá" na religião. Há "contratos" em que o crente "paga" antes de receber, como na novena. Às vezes, quando não recebe a graça, pode "contrariar" os santos, como ocorria no Sertão Nordestino: não chovendo no dia de São José, os crentes trocavam as imagens dos santos de suas igrejas que, enquanto não chovesse, não retornariam aos seus devidos lugares. ${ }^{10}$ Diversas letras de músicas retratam promessas feitas; uma delas é a da canção Pingo d'água, que possui diversas gravações.

\section{PINGO D'ÁGUA (Raul Torres/João Pacífico)}

Eu fiz a promessa/ Pra que Deus mandasse chuva/ Pra crescer a minha roça/ E vingar a criação/ Pois veio a seca/ E matou meu cafezal/ Matou todo o meu arroz/ E secou meu argodão.

Nesta colheita/ Meu carro ficou parado/ Minha boiada carreira/ Quase morre sem pastar/ Eu fiz a promessa/ Que o primeiro pingo d'água/ Eu moiava a frô da Santa/ Que tava em frente do altar.

Eu esperei/ Uma sumana/ Um mês inteiro/ A roça tava tão seca/ Dava pena a gente ver./ Oiava o céu/ Cada nuvem que passava/ Eu da santa me alèmbrava/ Pra promessa não esquecer.

Em pouco tempo/ A roça ficou viçosa/ A criação já pastava/ Floresceu meu cafezal/ Fui na capela/ E levei três pingo d'água/ Um foi o pingo da chuva/ Dois caiu do meu oiá.

${ }^{10}$ A este respeito, ver a letra de A permuta dos santos, de Chico Buarque e Edu Lobo. Foi gravada pela primeira vez em 1988 pelo grupo Garganta Profunda, no LP Dança da meia lua (Rio de Janeiro: 
Nos centros religiosos brasileiros do catolicismo popular, o comércio local gira em torno do sagrado e, muitas vezes, é difícil distinguí-lo do profano. Aqueles que têm lojas ou barracas fixas são, normalmente, os com melhores condições de vida na cidade. Mas a presença de romeiros também atrai atividades de lazer e, em locais onde a maioria que peregrina é de origem rural, também o comércio de bugigangas "modernas" ou eletrônicas, que possibilitam o contato com as "novidades" do progresso. O sagrado, portanto, impõe uma valorização que estabelece a segregação espacial existente no lugar; e "é possível reconhecer três espaços diferenciados entre si: o espaço sagrado, o espaço profano diretamente vinculado às atividades religiosas, e o espaço profano indiretamente vinculado ao sagrado." (ROSENDAHL, 1995:66) Neste último, o poder do romeiro na modelação do espaço é menor pois possui a maioria das funções voltada aos habitantes fixos.

Em áreas próximas a Campinas (SP) existem algumas cidades nas quais o turismo religioso é significativo, como em Pirapora do Bom Jesus e Santana do Parnaíba. Mas são centros de peregrinação em finais de semana ou em períodos de festas religiosas, apesar da Igreja Matriz de Sant'Ana (em Santana do Parnaíba) ser considerada a mãe de diversos santuários. Para alguns autores, foi de Santana do Parnaíba (SP) que saiu a imagem original de Nossa Senhora Aparecida, a padroeira do Brasil, levada ao vale do Paraíba paulista por parnaibanos que para lá se deslocaram. A hierofania ocorrida em Aparecida do Norte a transformou no principal santuário religioso do país e em uma cidade com função eminentemente religiosa.

A letra na seqüência retrata um romeiro que não sabe rezar, que vai a Aparecida do Norte como um ato de fé. Faz referências a Pirapora e foi sucesso nacional na voz de Elis Regina (1945-1982) e também na de seu autor.

\section{ROMARIA (Renato Teixeira)}

É de sonho e de pó/ O destino de um só/ Feito eu perdido/ Em pensamentos sobre o meu cavalo./ É de laço e de nó/ De gibeira o jiló/ Dessa vida cumprida a sol.

Sou caipira Pirapora/ Nossa Senhora de Aparecida/ Ilumina a mina escura/ E funda o trem da minha vida. (bis)

O meu pai foi peão/ Minha mãe solidão/ Meus irmãos perderam-se/ Na vida à custa de aventuras/ Descasei, joguei,/ Investi, desisti,/ Se há sorte, eu não sei, nunca vi.

Sou caipira Pirapora/ Nossa Senhora de Aparecida/ Ilumina a mina escura/ E funda o trem da minha vida. (bis)

Me disseram, porém/ Que eu viesse aqui/ Pra pedir de romaria e prece/ Paz nos desaventos/ Como eu não sei rezar/ Só queria mostrar/ Meu olhar, meu olhar, meu olhar.

Sou caipira Pirapora/ Nossa Senhora de Aparecida/ Ilumina a mina escura/ E funda o trem da minha vida. (bis)

Som Livre, p1988, lado A, faixa 3). No ano seguinte por Chico, no LP Chico Buarque (São Paulo: RCA Victor/BMG, p1989, Lado A, faixa 5). 
No Brasil, não é incomum um romeiro não participar das cerimônias religiosas. Ele "declara que veio pagar promessa; algumas vezes não se considera católico e afirma não gostar de padres. Mas faz promessa sempre que precisa: 'Sempre sou atendido e volto para pagar'." (ROSENDAHL, 1997:139) Isto ajuda a explicar porque a Sala dos Milagres existente em quase todos os santuários católicos é uma visita obrigatória para a maioria. Entretanto, o "fato de pessoas fazerem o culto juntas, orarem no mesmo lugar, ou fazerem parte de uma paróquia não acarreta necessariamente um sentimento de integração e de comunidade religiosa." (2003:206)

A "capital mariana do Brasil" localiza-se no interior da megalópole em formação entre São Paulo e Rio de Janeiro e é atualmente um dos principais centros mundiais de peregrinação cristã. A hierofania ocorreu quando, em 1717, uma imagem de Nossa Senhora da Conceição foi "pescada" nas águas do Paraíba do Sul. Até o início do século XX, sua veneração foi local e regional; em 1904, dentro do processo de romanização da Igreja Católica, foi coroada Rainha do Brasil. O crescimento provocado pelo Santuário permitiu sua emancipação do município de Guaratinguetá (em 1928) e, em 1931, com o governo Vargas - um governo que estimulava manifestações culturais com vista à formação de uma identidade nacional -, foi oficializada como Padroeira da Nação. Em 1951 foi fundada a Rádio Aparecida, um marco importante no processo de difusão da veneração e de modernização técnica da evangelização. A Rádio Aparecida se constituiu em uma das poucas emissoras que cobria o território brasileiro (a outra era a Rádio Nacional); hoje transmite em todas as ondas e pode ser sintonizada em mais de 20 países.

A marca de Nossa Senhora Aparecida é tão grande que sua presença em nosso cancioneiro é marcante. Como demonstra a letra a seguir, na qual o cantor Roberto Carlos solicita a sua proteção. Esta música, gravada em 1993, embora não composta com finalidades estritamente religiosas, é executada em diversas igrejas católicas.

\section{NOSSA SENHORA (Roberto Carlos / Erasmo Carlos)}

Cubra-me com seu manto de amor/ Guarda-me na paz desse olhar/ Cura-me as feridas e a dor/ me faz suportar./ Que as pedras do meu caminho/ Meus pés suportem pisar/ Mesmo ferido de espinhos/ me ajude a passar./ Se ficaram mágoas em mim/ Mãe tira do meu coração/ E aqueles que eu fiz sofrer/ peço perdão./ Se eu curvar meu corpo na dor/ Me alivia o peso da cruz/Interceda por mim minha mãe/ junto a Jesus.

Nossa Senhora/ me dê a mão/ Cuida do meu coração/ Da minha vida/ Do meu destino/ Nossa Senhora/ me dê a mão/ Cuida do meu coração/ Da minha vida/ do meu destino/ Do meu caminho/ Cuida de mim.

Sempre que o meu pranto rolar/ Ponha sobre mim suas mãos/ Aumenta minha fé e acalma/ o meu coração./ Grande é a procissão a pedir/ A misericórdia o perdão/ A cura do corpo e pra alma/ a salvação./ Pobres pecadores, oh Mãe/ Tão necessitados de vós/ Santa Mãe de Deus tem piedade/ de nós./ De joelhos aos vossos pés/ Estendei a nós vossas mãos/ Rogai por todos nós vossos filhos/ meus irmãos.

Nossa Senhora/ me dê a mão/ Cuida do meu coração/ Da minha vida/ Do meu destino/ Nossa Senhora/ me dê a mão/ Cuida do meu coração/ Da minha vida/ Do meu destino/ Do meu caminho/ Cuida de mim.) 
Mesmo compositores da nova geração não deixam de homenagear aquela que foi coroada rainha do Brasil. O marianismo continua presente entre os integrantes da Igreja Católica Romana. A letra de Mãe de Verdade, do jovem Jair Oliveira, gravada por seu pai Jair Rodrigues em 2002, ilustra este fato.

\section{MÁE DE VERDADE (Jair de Oliveira)}

\section{É padroeira de minha vida/ Mãe de verdade, Aparecida (2x)}

Maria de muitos milagres/ Maria de pescadores/ Maria de toda coragem/ De todo valor/ De muitos amores.

Meu canto pra ti é homenagem/ Teu nome pra mim é uma vida/ Eu choro de felicidade $(2 \mathrm{x}) /$ Me sinto à vontade/ Em tua acolhida.

É padroeira de minha vida/ Mãe de verdade, Aparecida/ Mãe de toda pureza/ Mãe de piedade/ Maria de toda beleza/ De todo esplendor, de toda humildade.

Meu canto pra ti é homenagem/ Teu nome pra mim é uma vida/ Eu choro de felicidade $(2 \mathrm{x}) / \mathrm{Me}$ sinto à vontade/ Em tua acolhida.

É padroeira de minha vida/ Mãe de verdade, Aparecida.

Em 1955, às vésperas do governo JK, se iniciou a construção de uma nova basílica imaginada de modo grandioso, como a reproduzir a imponência da Basílica de São Pedro, em Roma, e, para alguns autores, "é muito significativa a construção de um templo romântico em plena era do concretismo arquitetônico." (OLIVEIRA, 1999:265) O projeto, segundo Oliveira (1999:268), foi inspirado em uma igreja de Washington, de estilo neo-romântico. O início foi demorado; foram doze anos para erguer a nave norte e a torre (de 20 andares e denominada "Brasília" em agradecimento à doação da estrutura metálica realizada por JK) mas, a partir da década de 1970, o ritmo da construção foi mais rápido, inclusive de uma grande e boa infra-estrutura social e de serviços. Em praticamente duas décadas foram construídas as naves sul, leste e oeste. No subsolo, há espaços para os romeiros se alimentarem, além de berçário, serviço médico etc., todos gratuitos. Os sanitários, "passaram de oito em 1967 para mais de novecentos em 1980." (OLIVEIRA, 1999:270) Foi nesse período, por doação do governo militar, que foi construída a "Passarela da Fé", ligando a basílica nova à antiga. A construção do "subsolo sócial", da passarela e do estacionamento foi decisiva para a ampliação ocorrida do número de romeiros.

O grande fluxo de peregrinos fez surgir, nos arredores da basílica, um intenso comércio de barraqueiros, um "camelódromo" semelhante aos existentes nas grandes e empobrecidas cidades brasileiras. É comum que romeiros levem objetos que simbolizem o lugar, como lembrança da peregrinação ou para colocar alguma réplica do elemento santificado em sua casa. Para os que vieram de localidades pequenas, também mercadorias não religiosas são colocadas à venda. No final da década de 1990, como uma ampliação do serviço de apoio ao romeiro, foi construída 
uma área comercial junto ao estacionamento, com praça de alimentação e dezenas de lojinhas, ironicamente chamado de "shopping da fé". Velas, medalhas, imagens são vendidas ao lado de roupas, CDs, bolsas, relógios e produtos eletrônicos, em uma mistura entre o sagrado e o profano. Um profano possibilitado pelo sagrado mas que não está mais no entorno do espaço sagrado. São as construções - os fixos - que permitem a diferenciação pois a impressão que se tem é de uma mistura de espaços, que o pro-fano não está mais em frente mas dentro.

No dia seis de janeiro é, normalmente, na tradição cristã, celebrado o Dia dos Reis, quando se rememora a chegada de supostos reis que ofereceram ouro simbolizando a realeza -, incenso - a divindade - e mirra ${ }^{11}$ - a humanidade. O Dia de Reis é mais comemorado em países europeus, sendo o dia de troca de presentes. "Nas tradições ibéricas trazidas ao Brasil, os Reisados ou as Folias de Reis são espetáculos tradicionais, já bem esquecidos entre os folguedos que apenas remanescem nos bairros rurais." (FERREIRA, 2006:04) O nome Folia era muitas vezes substituído por Companhia em razão do sentido meio pejorativo que pode possuir o primeiro termo. A Folia de Reis no Brasil existe ainda, por exemplo, no Vale do Paraíba do Sul, onde esteve normalmente associada à presença de uma Companhia, representada por uma Bandeira, que se apresentava a uma casa na qual estava montado um presépio. Nenhuma destas casas poderia negar a entrada da Companhia dos Reis e da Bandeira - representada por seu alferes - normalmente à noite. Em Piquete (SP), onde se podia notar a influência de Reisados, os integrantes cantavam "[...] modinhas acompanhadas de rabecões, violas, pandeiros, caixas, vozes repetidoras dos estribilhos fáceis e coreografias dançadas prolongadamente. Com roupas coloridas, máscaras nas faces, muitas fitas coloridas e flores singelas feitas de papel, os grupos de cantadores varavam as noites nas visitas aos presépios." (FERREIRA, 2006:04)

A bandeira era normalmente confeccionada em tecido brilhante, acetinado e nela apareciam pintadas a cena do presépio, a estrela de Belém, Maria, José, Jesus menino e os Reis. Um símbolo de respeito e veneração, a bandeira era acompanhada de diversas fitas para serem beijadas pelos fiéis. As referências existentes evocam gestos medievais e cantorias utilizadas em castelos europeus. No Brasil, a influência portuguesa modulou-se em outras cantigas, ganhou corpo e hoje luta para não morrer. Possui características do ciclo natalino, mistura o religioso (a evocação que os Reis Magos, orientados por uma estrela, fizeram em busca do local de nascimento de Jesus) ao profano. E continua em algumas localidades pequenas ou no meio rural.

No CD do multi-instrumentista pernambucano Antonio Nóbrega intitulado Madeira que cupim não rói, do selo Eldorado, gravado em 1997, existe uma transcrição e adaptação do Reisado, de uma Cantiga de Santa Maria, compilada pelo rei Afonso X, o Sábio, de Castela.

"Resina odorífera e medicinal, de origem africana, usada como incenso e em perfumes. 


\section{ABRIÇÃO DE PORTAS}

(Domínio Público - Adaptaçāo: Antonio Nóbrega/Wilson Freire)

Salve essa casa,/ nobre morada./ Nova jornada/ vamos começar.

Nossa festa vai principiar./ Com rabecas, bombos e violas/ hoje aqui viemos festejar,/ render graças à vida nessa hora.

Abram as portas/ para o meu Reisado./ Cantos e loas/ vamos entoar.

Gravada em 1971 por Tim Maia, a letra da canção A Festa do Santo Reis também nos remete a esta data e a símbolos usados pelos integrantes da Folia de Reis.

\section{A FESTA DO SANTO REIS (Márcio Leonardo)}

Hoje é o dia do Santo Reis/ Anda meio esquecido/ Mas é o dia da festa de Santo Reis/ Hoje é o dia do Santo Reis/ Anda meio esquisito/ Mas é o dia da festa do Santo Reis. Eles chegam tocando sanfona e violão/ Os pandeiros de fita carregam sempre na mão/ Eles vão levando, levando o que pode/ Se deixar com eles, eles levam até os bode/ É os bode da gente, é os bode mééé.../ É os bode da gente, é os bode mééé...

Hoje é o dia do Santo Reis/ Hoje é o dia do Santo Reis (Hoje é o dia)/ Hoje é o dia do Santo Reis (É o dia da festa).

Tavinho Moura compôs Calix Bento a partir de uma letra adaptada da Folia de Reis do norte de Minas Gerais. Calix é uma maneira da população da região falar ao se referir à cálice. Gravada em 1976 por Milton Nascimento no LP Geraes, alcançou grande popularidade.

\section{CALIX BENTO (Tavinho Moura)}

ó Deus salve o oratório/ Ó Deus salve o oratório/ Onde Deus fez a morada/ Oiá, meu Deus, onde Deus fez a morada, oiá.

Onde mora o calix bento/ Onde mora o calix bento/ E a hóstia consagrada/ Óiá, meu Deus, e a hóstia consagrada, oiá.

De Jessé nasceu a vara/ De Jessé nasceu a vara/ E da vara nasceu a flor/ Oiá, meu Deus, da vara nasceu a flor, oiá.

E da flor nasceu Maria/ E da flor nasceu Maria/ De Maria o Salvador/ Oiá, meu Deus, de Maria o Salvador, oiá

Ivan Lins e Vitor Martins fizeram uma música com base nas Bandeiras, mas que também possuía uma visão política, pois foi gravada em um período (1978) em que o país ainda vivia sob uma ditadura. Daí as referências ao homem livre, à procura de melhores dias, ao rei que nascerá do povo e outras. Mas o estilo relembra algo das Bandeiras tradicionais, colocando nesta letra o menino que nasceu e os Reis Magos. 


\section{BANDEIRA DO DIVINO (Ivan Lins/ Vitor Martins)}

Os devotos do Divino/ Vão abrir sua morada/ Pra bandeira do menino/ Ser bem vinda, ser louvada, ai, ai. (bis)

Deus nos salve esse devoto/ Pela esmola em vosso nome/ Dando água a quem tem sede,/ Dando pão a que tem fome, ai, ai. (bis)

A bandeira acredita/ Que a semente seja tanta/ Que essa mesa seja farta,/ Que essa casa seja santa, ai, ai. (bis)

Que o perdão seja sagrado,/ Que a fé seja infinita/ Que o homem seja livre,/ Que a justiça sobreviva, ai, ai. (bis)

Assim como os três Reis Magos/ Que seguiram a estrela guia/ A bandeira segue em frente/ Atrás de melhores dias, ai, ai. (bis)

No estandarte vai escrito/ Que ele voltará de novo/ E o rei será bendito/ Ele nascerá do povo, ai, ai. (bis)

A alteração dos valores e da cultura tem atingido o âmago de algumas religiões, sobretudo as mais tradicionais. Questiona-se a moral sexual, a condição feminina ante a dominação do homem, o próprio conceito de autoridade. Este relativismo moral, essa perda de padrões coletivos, pode levar a sociedade a uma anomia ou à procura de visões fundamentalistas. Já existe uma pluralidade religiosa, mas é importante que se mantenham alguns padrões coletivos e que sejam respeitados, pois existe no país uma "competição entre as igrejas, onde as regras do marketing são aplicadas aos meios religiosos numa clara busca de prosélitos." (MALVEZZI, 2004:18) A tendência do capital religioso em ser acumulado e concentrado nas mãos de um grupo de administradores deste sagrado pode ser observada, por exemplo, em “filiais da Igreja Universal do Reino de Deus, na qual o capital simbólico está concentrado nas mãos de um grupo de 'empresários' do sagrado, que manipulam o estoque de bens simbólicos disponíveis à sociedade.” (ROSENDAHL, 2003:191)

É importante que a atual geração tenha idéia de que seu comportamento frente às religiões hoje pode ser livre graças a pessoas que lutaram no passado. Muitos foram perseguidos, outros foram arrojados e enfrentaram perseguições, dificuldades e calúnias. É importante lembrar que existem fatos históricos que fizeram com que hoje se tivesse mais liberdade. Isto é que permitiu que o conjunto Titãs gravasse normalmente a música Igreja em 1986, no LP Cabeça Dinossauro; puderam dizer que não gostavam de padre, de Cristo, do papa e que não acreditavam em nada, afirmando fatos totalmente diferentes do que acreditavam seus avós. ${ }^{12}$

\footnotetext{
${ }^{12} \mathrm{O}$ mesmo ocorreu com o conjunto Plebe Rude quando lançou a música Sem Deus, Sem Lei, em 1993, no CD Mais raiva do que medo, na qual diz que vive sem Deus, sem lei, sem religião e sem dogma. (Sem Deus, Sem Lei, Philippe Seabra/André X) "Sem Deus, sem Lei/ Só eu e você/ Sem Deus, sem Lei/Só eu e você/ Você me diz/ Podemos conseguir/Sem Deus, sem Lei// Vivo sem religião/ Sem o dogma e a perseguição/ Eu não preciso acreditar// Levanta o rosto vai/ No que não creio eu já deixei pra trás/ Essa é a minha lei, eu e você."
} 


\section{IGREJA (Nando Reis)}

Eu não gosto de padre/ Eu não gosto de madre/ Eu não gosto de frei.

Eu não gosto de bispo/ Eu não gosto de Cristo/ Eu não digo amém.

Eu não monto presépio/ Eu não gosto do vigário/ Nem da missa das seis.

Eu não gosto do terço/ Eu não gosto do berço/ De Jesus de Belém.

Eu não gosto do papa/ Eu não creio na graça/ Do milagre de Deus.

Eu não gosto da igreja/ Eu não entro na igreja/ Não tenho religião.

Atualmente, no Brasil, não existe mais vergonha em se dizer "crente"; aliás, isso tem sido, inclusive, um motivo de auto-afirmação de parcela da população. Entretanto, nem todas as práticas religiosas instaladas no país são sérias, nem todas possuem uma teologia consistente. É isto que retratam algumas músicas de nosso cancioneiro, fazendo graça com características de algumas igrejas, que exploram a ingenuidade de muitos para obtenção de recursos pecuniários para determinados pastores. É o caso da letra Ou dá ou desce, cantada por Zé Geraldo:

\section{OU DÁ OU DESCE (Zé Geraldo)}

Hei escuta aqui você aí/ Meu senhor que está sentado/ Do outro lado da TV/ Eu vim aqui fazer minha prestação/ De contas pra você/ Eu me dirijo a todo povo brasileiro/ Eu sou pastor por vocação/ Me chamam bispo isso mesmo eu vivo é disso/ Essa é a minha profissão.

Tenho cadeia de hotéis no Hawai/ Fazenda no Texas/ Um sítio em Parati/ O gado é de primeira, muito bom/ Automóveis do ano/ Cobertura no Leblon/ Triplex na Vieira Souto/ Uma casa de praia na Orla do Guarujá/ Pra investir e garantir meu capital/ Eu tenho na Bahia umas fazendas de cacau.

Eu tenho poço de petróleo no Iraque/ De araque caro irmão/ Eu tenho igrejas de montão/ Frequento a bolsa de valores/ De São Paulo, Nova Iorque/ Eu tenho rede de jornal, rádio e televisão/ Tenho uma verba aplicada/ Na Europa e na América/ Que é melhor deixar por lál Pra encerrar as contas desse meu calvário/ Já que não tem mais jeito/ Eu vou falar do meu salário/ O meu salário não é feito/ De tostões e de mil réis/ Eu vivo da bondade e doações/ Dos meus fiéis.

Obrigado irmãos/ Obrigado/ Ou dá ou desce! Aleluia!

Também é o caso da letra de Pastor João e a Igreja Invisível, de Raul Seixas e Marcelo Nova, lançada no disco feito pelos dois em 1989, chamado "A Panela do Diabo" (WEA, faixa 6).

\section{PASTOR JOÃO E A IGREjA INVISÍVEL (Raul Seixas/Marcelo Nova)}

Eu não sei se o céu ou o inferno/ Qual dos dois você vai ter que encarar/ E foi pra não the deixar no horror/ Que eu vim para lhe acalmar/Se o pecado anda sempre ao seu lado/ Se o demônio vive a lhe tentar/ Chegou a luz no fim do seu túnel, minha 
filha/ O meu cajado vai the purificar.

Pois eu transformo água em vinho,/ Chão em céu, pau em pedra, cuspe em mel/ Pra mim não existe impossível/ Pastor João e a igreja invisível. (bis)

Para os pobres e desesperados/ $\mathrm{E}$ todas as almas sem lar/ Vendo barato a minha nova água benta/ Três prestações, qualquer pode pagar/ O sucesso da minha existência/ Está ligado ao exercício da fé/ Pois se ela remove montanhas/ Também traz grana e um monte de mulher.

Pois eu transformo água em vinho,/ Chão em céu, pau em pedra, cuspe em mel/ Pra mim não existe impossível/ Pastor João e a igreja invisível. (bis)

Existem territórios religiosos demarcados (como a paróquia, por exemplo), nos quais o acesso é controlado e dentro deles a autoridade é de um profissional religioso. Sua existência favorece o exercício da fé do devoto e ele encarna a relação simbólica entre cultura e espaço, transformando-se em um "geossímbolo". "A religião só se mantém se sua territorialidade for preservada e, neste sentido, pode-se acrescentar que é pela existência de uma religião que se cria um território e é pelo território que se fortalecem as experiências religiosas coletivas ou individuais." (ROSENDAHL, 2003:195) Entretanto, se diversos locais sagrados possuem uma localização real, esta noção não se associa necessariamente a uma territorialidade definida pois existem locais sagrados imaginários, cujas fronteiras são definidas pela imaginação.

As experiências ligadas à religião são repletas de significados, possuem uma dimensão espacial e, por isso, também interessam à Geografia. Há a necessidade de compreender a força da religião modificando a paisagem, interferindo nas ações humanas e, portanto, na própria organização espacial das sociedades. Existe, é claro, um simbolismo destes lugares considerados sagrados e ainda práticas espaciais ligadas aos mesmos.

Se a religião é um sistema cultural, um sistema de símbolos com a função de tornar atos e valores humanamente significativos, a existência de lugares hierofânicos torna-os centros extraordinários, que produzem na paisagem formas e funções; um dos papéis da Geografia é explicar o que produziu tal paisagem.

Resumo: O artigo discute o uso da música e sua função nas escolas, fazendo análises sobre o estudo da religião pela Geografia, sobre os espaços geográficos considerados sagrados e sobre as características e o papel da religião no Brasil, incluindo letras da Música Popular Brasileira (MPB) para colaborar na discussão a respeito do tema. Discute também o sincretismo religioso e a cidade de Aparecida do Norte (SP), e cita letras de músicas que criticam o papel de instituições religiosas e/ou de membros de sua hierarquia. Além disso, coloca diversas letras de MPB que podem ser utilizadas em sala de aula de ensino fundamental e médio pois pretende, basicamente, proporcionar alternativas de ensino para quem ministra aulas de Geografia. 
Palavras-chave: Religião - Geografia - letras da MPB - Romaria - Sala de aula.

RELIGIOUS SPACE, GEOGRAFIA AND BRAZILIAN POPULAR MUSIC: A PROPOSAL FOR HIGH SCHOOL

Abstract: The article discusses the use of music and its role at school, analyzing the study of religion from Geography's point of view, the Geographical locations considered sacred and also the features and the role of religion in Brazil, enriching the analysis with lyrics of the Brazilian Popular Music (MPB). It discusses as well the religious syncretism and the city of Aparecida do Norte (SP), mentioning lyrics that criticize the role of the religious institutions and/or members of its hierarchy. Besides, it includes MPB lyrics that can be used at classroom at different school levels. Mainly, it intends to provide alternatives of teaching for Geography teachers.

Key Words: Religion - Geography - MPB lyrics - Pilgrimage - Classroom

\section{BIBLIOGRAFIA}

BRANDÃO, Carlos Rodrigues. 1999. O afeto da terra. Campinas: ed. da UNICAMP. (c. pesquisas)

CAVALCANTE, Antônio Mourão. 1998. Légua tirana, um turismo de fé. In: $D a$ cidade ao campo: a diversidade do saber-fazer turístico. Fortaleza: UECE; p. 144-152.

CUNHA, Euclides da. 1982. Os sertões. Campanha de Canudos. São Paulo: Abril Cultural.

DAVID, Célia Maria. Música no ensino fundamental: uma experiência a partir da canção. 2004. In: David, Célia M.; GUIMARÃES, J. Gerado M. (orgs.). Pedagogia cidadã: cadernos de formação: vivências artístico-pedagógicas. São Paulo: UNESP, Pró-reitoria de Graduação, p. 59-74.

FARIA, Ernesto. 1992. Dicionário escolar latino-português. $6^{\mathrm{a}}$ ed. Rio de Janeiro: FAE.

FERREIRA, Dóli de Castro. 2006. No Dia de Reis: a Folia e a Companhia dos Reis. O Estafeta.

Piquete: Fundação Christiano Rosa, a. X, n. ${ }^{\circ}$ 109, fev. 2006, p. 04.

LEMOS FILHO, Arnaldo. 1996. Os catolicismos brasileiros. Campinas: Alínea.

MALVEZZI, Roberto. 2004. Crise de sustentabilidade, crise civilizatória. In: CNBB. 
Mutirão por um novo Brasil. $1^{\text {a }}$ ed. Brasília: Conferência Nacional dos Bispos do Brasil, p. 07-21.

NADAI, Elza, NEVES, Joana. 1991. História do Brasil: da Colônia à República. $14^{a}$ ed. São Paulo: Saraiva.

OLIVEIRA, Christian D. M. de. 1998. Religiosidade popular na pósmodernidade: um ritual turístico?. In: Da cidade ao campo: a diversidade do saber-fazer turístico. Fortaleza: UECE, 153-160.

1999. A monumentalidade do templo e da romaria. Uma periodização geográfica das peregrinações à Basílica de Aparecida. In: Turismo e geografia: reflexões teóricas e enfoques regionais. 2a ed. São Paulo: HUCITEC, 262-272.

RIBEIRO, Marcus V. et al. 1988. Brasil vivo, v. II: A República. Petrópolis: Vozes.

ROSENDHAL, Zeny. 1993. O sagrado como elemento da coesão rural. Análise de dois pontos de convergência religiosa: Muquém e Santa Cruz dos Milagres. Revista Brasileira de Geografia. Rio de Janeiro: IBGE, jan/dez. 55 (1/4): 207214.

1995. O espaço sagrado: o exemplo de Porto das Caixas, Baixada Fluminense. Revista Brasileira de Geografia. Rio de Janeiro: IBGE, jan/mar, 57 (1): 53-72.

1996. O sagrado e o urbano: gênese e função das cidades. Espaço $e$ cultura. Rio de Janeiro: UERJ/NEPEC, jun. 1996, n. 2, 26-39.

1997. O Sagrado e o Espaço. In: CASTRO, Iná Elias; GOMES, Paulo César da Costa; CORREAA, Roberto Lobato (orgs.). Explorações geográficas: percursos no fim do século. Rio de Janeiro: Bertrand Brasil, p. 119-153.

1998. Percepção, vivência e simbolismo do sagrado no espaço: peregrinos e turistas religiosos. In: Da cidade ao campo: a diversidade do saber-fazer turístico. Fortaleza: UECE, 134-143.

2003. Espaço, Cultura e religião: dimensões de análise. In: CORRÊA, Roberto Lobato; ROSENDHAL, Zeny (orgs.).Introdução à Geografia Cultural. Rio de Janeiro: Bertrand Brasil, p. 187-224.

SANTOS, Milton. 1978. Por uma geografia nova. São Paulo: HUCITEC/EDUSP. 


\section{Referências a documentos sonoros (LPs e CDs)}

AZEVEDO, Geraldo; VINICIUS, Marcus. Novena. Intérpretes: Geraldo Azevedo, Vital Farias e Xangai. In: Elomar, Geraldo Azevedo, Vital Farias e Xangai. Cantoria 1. Rio de Janeiro: Kuarup Discos, p. 1984, 1 CD, faixa 02.

BEN, Jorge. Meu glorioso São Cristóvão. Intérpretes: Gilberto Gil e Jorge Ben. In: . Gil e Jorge. Rio de Janeiro: Philips, p1975, 1 disco sonoro, lado A, faixa 01.

CAPIBA. Festa da padroeira. Intérprete: Antonio Nóbrega. In:

Pernambuco falando para o mundo. São Paulo: Distribuidora Eldorado, p1999, $1 \mathrm{CD}$, faixa 02 .

CARLOS, Roberto; CARLOS, Erasmo. Jesus Cristo. Intérprete: Roberto Carlos. In: . Roberto Carlos. Rio de Janeiro: CBS, p1970, 1 disco sonoro, lado B, faixa 03 .

Nossa Senhora. Intérprete: Roberto Carlos. In: Roberto

Carlos. Rio de Janeiro: Colúmbia, p1993, 1 CD, faixa 05.

CAYMMI, Dorival. Promessa de Pescador. Intérpretes: Nana, Dori e Danilo. In: Para Caymmi - 90 anos. [São Paulo]: Warner Music, p2005, 1 CD, faixa 05 (série Dose Dupla - 1 CD e 1 DVD)

DOMÍNIO Público; adaptação: NÓBREGA, Antonio; FREIRE, Wilson. Abrição de Portas. Intérprete: Antonio Nóbrega. In: Madeira que cupim não rói. São Paulo: Distribuidora Eldorado, p1997, 1 CD, faixa 01

GERALDO, Zé. Ou dá ou desce. Intérprete: Zé Geraldo. In: Acústico. São Paulo: Paradox Music, p1996, 1 CD, faixa 13.

GIL, Gilberto. Andar com fé. Intérprete: Gilberto Gil. In: Um Banda Um. São Bernardo do Campo (SP): EMI-Odeon, p1982, 1 disco sonoro, lado B, faixa 01.

Se eu quiser falar com Deus. Intérprete: Gilberto Gil. In: Luar. São Bernardo do Campo (SP): EMI-Odeon, p1981, 1 disco sonoro, lado B, faixa 05.Também in: p1990, 1 CD, faixa 03. . A gente precisa ver o luar. São Paulo: Warner Music,

GIL, Gilberto; Nascimento, Milton. Sebastian. Intérpretes: Milton Nascimento e 
Gilberto Gil. In: . Gil \& Milton. Rio de Janeiro: WEA, p2000, 1 CD, faixa 01 .

LOBO, Edu; GUERRA, Ruy. Reza. Intérprete: Edu Lobo. In: $A$

Música de Edu Lobo por Edu Lobo. Rio de Janeiro: Forma, p1965, 1 disco sonoro, lado B, faixa 1 (com a participação de Tamba Trio)

LEONARDO, Márcio. A Festa do Santo Reis. Intérprete: Tim Maia. In: Tim Mia. Rio de Janeiro: Polydor/Polygram, p1971, lado a faixa 1.

LINS, Ivan; MARTINS, Vitor. Bandeira do Divino. Intérprete: Ivan Lins. In: . Nos dias de hoje. São Bernardo do Campo (SP): EMI-Odeon, p1978, 1 disco sonoro, lado A, faixa 3.

MAIA, Tim; CASSIANO. Padre Cícero. Intérprete: Tim Maia. In: Tim Mia. Rio de Janeiro: Polygram, p1970, 1 disco sonoro, lado A, faixa 4 (CD p1993)

MARTINS, Herivelto. Ave Maria do Morro. Intérprete: João Gilberto. In: João. Rio de Janeiro: Polygram/Phillips, p1991, 1 disco sonoro, lado B, faixa 03.

MOURA, Tavinho. Calix Bento. Intérprete: Milton Nascimento. In: Geraes. São Bernardo do Campo (SP): EMI-Odeon, p1976, 1 disco sonoro, lado 1, faixa 02 (letra adaptada de Folia de Reis do norte de Minas Gerais).

MOURA, Tavinho; BRANT, Fernando. Paixão e Fé. Intérprete: Milton Nascimento. In: Clube da Esquina 2. Rio de Janeiro: EMI, pl978, 2 discos sonoros, LP 1, Lado A, faixa 04 (com a participação dos Canarinhos de Petrópolis)

OLIVEIRA, Jair. Mãe de Verdade. Intérprete: Jair Rodrigues. In: Intérprete. [São Paulo]: Trama, p2002, I CD, faixa 11.

SEABRA, Philippe; X, André. Sem Deus, Sem Lei. Intérprete: Plebe Rude. In: Mais raiva do que medo. São Paulo: Natascha, p1993, 1 CD, faixa 02.

POWELL, Baden; MORAES, Vinícius de. Canto de Ossanha. Intérpretes: Baden Powell, Vinícius de Moraes e Quarteto em Cy. In: Os afro-sambas. Rio de Janeiro: Forma, p. 1966, 1 disco sonoro, lado A, faixa 01.

Canto de Xangô. . Intérpretes: Baden Powell, Vinícius de Moraes e Quarteto em Cy. In: Os afro-sambas. Rio de Janeiro: Forma, p. 1966, 1 disco sonoro, lado A, faixa 02. 
Canto de Iemanjá. Intérpretes: Baden Powell, Vinícius de

Moraes e Dulce Nunes. In: Os afro-sambas. Rio de Janeiro: Forma, p. 1966, 1 disco sonoro, lado A, faixa 04.

; __ Canto do Caboclo da Pedra Preta. Intérpretes: Baden Powell, Vinícius de Moraes e Quarteto em Cy. In: Os afro-sambas. Rio de Janeiro:

Forma, p. 1966, 1 disco sonoro, lado B, faixa 02.

;____ Canto de Xangô. Intérpretes: Baden Powell, Vinícius de Moraes e Quarteto em Cy. In: . Os afro-sambas. Rio de Janeiro: Forma, p. 1966, 1 disco sonoro, lado A, faixa 02.

REIS, Nando. Igreja. Intérprete: Titãs. In: Cabeça Dinossauro. São Paulo: WEA, p1986, 1 disco sonoro, lado A, faixa 03.

ROCA, Geraldo. Jesus Menino. Intérprete: Almir Sater. In: Terra dos Sonhos. [s.1.]: Velas, p1994, 1 CD, faixa 07.

SEIXAS, Raul; NOVA, Marcelo. Pastor João e a Igreja Invisível. Intérprete: Marcelo Nova. In: Diversos. O Baú do Raul: uma homenagem a Raul Seixas. Rio de Janeiro: Som Livre, p2004, 2 CDs, CD1, faixa 05.

TEIXEIRA, Renato. Romaria. Intérprete: Renato Teixeira. In: Romaria. São Paulo: RCA Victor, p1978, 1 disco sonoro, lado 2, faixa 01.

TORRES, Raul; PACÍFICO, João. Pingo d'água. Intérprete: Grupo Corda \& Voz. In: Corda \& Voz. São Paulo: Estúdio Eldorado, p[197-], 1 disco sonoro, lado A, faixa 03.

VALENTE, Assis. Boas Festas. Intérprete: Carlos Galhardo. In: diversos. História da Música Popular Brasileira - Assis Valente - fascículo 14. São Paulo: Abril Cultural, p. 1970, 1 disco sonoro, lado 1, faixa 4. 